\title{
KAJIAN PENGOBATAN TRADISIONAL CACAR MENURUT TERJEMAHAN LONTAR USADA KACACAR
}

\author{
I Nyoman Gede Tri Sutrisna ${ }^{1}$, Ni Luh Gede Widyastuti ${ }^{2}$, Kadek Duwi Cahyadi ${ }^{3}$ \\ 1,3 Prodi S1 Farmasi, Sekolah Tinggi Farmasi Mahaganesha \\ ${ }^{2}$ Prodi D3 Farmasi, Akademi Farmasi Saraswati Denpasar \\ Email korespondensi : trisutrisna@farmasimahaganesha.ac.id
}

\begin{abstract}
ABSTRAK
Pengobatan tradisional di Bali merupakan konsep budaya Bali yang digunakan secara turuntemurun. Usada adalah pengetahuan pengobatan tradisional Bali sebagai sumber konsep untuk memecahkan masalah di bidang kesehatan. Penyembuhan (usada) terdapat dalam suatu lontar yang disebut dengan lontar usada. Lontar Usada Kacacar merupakan salah satu lontar usada yang membahas mengenai penyakit cacar. Tujuan penelitian ini yaitu mengetahui informasi yang terkandung dalam Lontar Usada Kacacar. Informasi meliputi jenis keadaan cacar, ramuan pengobatan, bentuk sediaan dan cara penggunaan. Selain itu, dalam penelitian dapat diketahui tumbuhan yang digunakan sebagai obat cacar tradisional. Pengobatan di Bali berdasarkan lontar usada, penelitian kali ini dilakukan pada lontar Usada Kacacar. Penelitian ini dilakukan secara deskriptif terhadap hasil terjemahan Lontar Usada Kacacar yang diterjemahkan oleh I Gusti Ngurah Wiriawan, S.S. Hasil terjemahan Lontar Usada Kacacar dibuat dalam bentuk tabel meliputi jenis keadaan cacar, ramuan pengobatan, cara penggunaan dan penggunaan mantra. Pada hasil tabel ditemukan informasi 100 ramuan pengobatan, 75 jenis keadaan cacar, 107 jenis tumbuhan, 10 jenis cara penggunaan dan 16 cara pengobatan yang disertai dengan mantra.
\end{abstract}

Kata kunci : Usada Kacacar, Cacar, Pengobatan cacar 


\section{ABSTRACT}

The Traditional medicine in Bali is a concept of Balinese culture that is used for generations. Usada is a knowledge of traditional Balinese medicine as a source of concepts to solve problems in the health sector. Healing (usada) is found in lontar called lontar usada. Lontar Usada Kacacar is one of the usada which discusses smallpox. The purpose of this study is to find out information contained in Lontar Usada Kacacar. Information includes the type of smallpox, treatment ingredients, dosage form and method of use. In addition, in research can be inform a plants that are used as traditional smallpox drugs. Healing in Bali is based on lontar, the research this time was carried out on eaves of Usada Kacacar. This research was conducted descriptively to the translation of Lontar Usada Kacacar translated by I Gusti Ngurah Wiriawan, S.S. The results of the translation of Lontar Usada Kacacar made in table form include the types of smallpox, medicinal herbs, how to use and use spells. The results of the table found information on 100 medicinal herbs, 75 types of smallpox, 107 types of plants, 10 types of methods of use and 16 methods of treatment accompanied by spells.

Keywords : Usada Kacacar, Smallpox, Smallpox treatment

\section{PENDAHULUAN}

Bangsa Indonesia merupakan bangsa dengan warisan budaya yang beragam dan beraneka tumbuhan yang dapat digunakan untuk pengobatan. Salah satu warisan budaya yang terdapat di Bali yaitu pengobatan tradisional. Pengobatan tradisional atau penyembuhan (usada) ini merupakan konsep budaya masyarakat Bali serta menjadi kebiasaan penyembuhan tersebut berlangsung secara turun-temurun. Lontar Usada terdiri dari berbagai macam jenis yaitu Lontar Usada Rare, Lontar Usada Taru Pramana, Lontar Usada Kuranta Bolong, Lontar Usada Kacacar dan lontar usada lainnya. Pada lontar Usada Kacacar memuat beberapa keadaan cacar, tanaman yang digunakan untuk formula dan cara pembuatan ramuan untuk pengobatan cacar. Lontar Usada Kacacar pada masa kini tidak terlalu dikenal oleh masyarakat luar.

Lontar Usada Kacacar yang merupakan acuan yang dapat digunakan dalam pengobatan cacar secara tradisional di Bali. Namun, sedikit masyarakat yang dapat mengetahui pengobatan cacar yang terkandung dalam Usada Kacacar dikarenakan kurangnya kemampuan untuk membaca lontar yang menggunakan bahasa Sansekerta. Dari latar belakang di atas dikaji masalah informasi apa yang terkandung dalam kajian pengobatan tradisional cacar menurut terjemahan lontar Usada Kacacar. Pada penelitian ini bertujuan untuk memberikan informasi yang terkandung pada kajian pengobatan tradisional untuk penyakit cacar menurut terjemahan Lontar Usada Kacacar meliputi gejala cacar, formula pengobatan, tumbuhan obat, cara penggunaan dan bentuk sediaan

\section{METODE PENELITIAN}

Penelitian yang dilakukan menggunakan metode deskriptif yang menggambarkan keadaan objek penelitian berdasarkan fakta- 
fakta yang telah ada. Lontar Usada Kacacar yang telah diterjemahkan oleh bapak I Gusti Ngurah Wiriawan S,S, kemudian dibuatkan dalam tabel mengenai gejala cacar, tumbuhan obat, bagian yang digunakan dan cara penggunaan formula.

Hasil terjemahan lontar, buku serta jurnal-jurnal mengenai kandungan pada tanaman obat yang terkait. Penelitian ini dilakukan dengan cara menerjemahkan lontar Usada Kacacar yang masih menggunakan bahasa Sansekerta menjadi bahasa Indonesia.
Proses penerjemahan dilakukan oleh Bapak I Gusti Ngurah Wiriawan, S.S.

\section{HASIL DAN PEMBAHASAN}

Pada terjemahan Lontar Usada Kacacar, diperoleh 100 formula pengobatan ilmiah yang menggunakan tumbuhan, 75 jenis obat untuk gejala cacar yang disebutkan pada lontar, 107 jenis tumbuhan dengan 10 cara penggunaan formula, selain itu terdapat pula 16 formula yang disertakan dengan doa/mantra

Tabel 1. Pengobatan Cacar menurut Lontar Usada Kacacar untu Pengobatan Luar

\begin{tabular}{|c|c|c|c|c|}
\hline Gejala Cacar & $\begin{array}{c}\text { Formula } \\
\text { Pengobatan }\end{array}$ & $\begin{array}{c}\text { Bagian Tumbuhan } \\
\text { yang Digunakan }\end{array}$ & $\begin{array}{c}\text { Cara } \\
\text { Penggunaan }\end{array}$ & Mantra \\
\hline \multirow[t]{3}{*}{ Penyakit cacar } & $\begin{array}{ll}\text { 1. Kakap/sirih } \\
\text { 2. Lengkuas } \\
\text { 3. Gamongan } \\
\text { 4. Kencur }\end{array}$ & $\begin{array}{ll}\text { 1. } & \text { Daun } \\
\text { 2. } & \text { Rimpang } \\
\text { 3. Umbi } \\
\text { 4. Rimpang }\end{array}$ & $\begin{array}{l}\text { Diparut, diperas, } \\
\text { kemudian } \\
\text { dipotong kecil- } \\
\text { kecil }\end{array}$ & - \\
\hline & $\begin{array}{ll}\text { 1. } & \text { Kambo- } \\
& \text { kambo } \\
\text { 2. } & \text { Cendana } \\
\text { 3. } & \text { Kelapa }\end{array}$ & $\begin{array}{ll}\text { 1. } & - \\
\text { 2. } & \text { Kayu } \\
\text { 3. } & \text { Kulit }\end{array}$ & \begin{tabular}{l}
\multicolumn{2}{l}{ Dipanggang } \\
sampai matang, \\
dicampur, diisi \\
dengan cendana \\
yang dikerik, \\
kelapa yang disisir \\
kemudian \\
dipanggang \\
sampai matang. \\
Semua itu \\
kemudian \\
dipotong kecil- \\
kecil
\end{tabular} & - \\
\hline & $\begin{array}{ll}\text { 1. } & \text { Sirih } \\
\text { 2. } & \text { Lunak } \\
\text { 3. } & \text { Buah } \\
& \text { badung } \\
\text { 4. } & \text { Kemiri }\end{array}$ & $\begin{array}{l}\text { 1. Daun } \\
\text { 2. Daging buah } \\
\text { 3. Kulit buah }\end{array}$ & $\begin{array}{l}\text { Dipanggang, } \\
\text { sampai tidak } \\
\text { menghasap } \\
\text { dibubuhi dengan } \\
\text { cara } \\
\text { menyemburkan. } \\
\text { Kelapa disisir, } \\
\text { dipanggang } \\
\text { sampai matang, } \\
\text { sudah matang } \\
\text { kemudian } \\
\text { dipotong kecil- } \\
\text { kecil sampai }\end{array}$ & - \\
\hline
\end{tabular}




\begin{tabular}{|c|c|c|c|c|}
\hline & & & $\begin{array}{l}\text { hancur } \text { (ketek). } \\
\text { Yang } \\
\text { disemburkan tadi } \\
\text { jangan } \quad \text { sampai } \\
\text { tebal, dibubuhi } \\
\text { dan diratakan } \\
\text { dengan cendana } \\
\text { harum, kemiri } \\
\text { krusuk (digoreng } \\
\text { tanpa minyak), air } \\
\text { beras putih }\end{array}$ & \\
\hline $\begin{array}{l}\text { Obat cacar } \\
\text { yang disembur } \\
\text { pada cacar yang } \\
\text { sudah pecah }\end{array}$ & $\begin{array}{ll}\text { 1. Kencur } \\
\text { 2. Kelapa } \\
\text { muda } \\
\text { 3. Cendana } \\
\text { jenggi } \\
\text { 4. Sirih }\end{array}$ & $\begin{array}{ll}\text { 1. } & \text { Rimpang } \\
\text { 2. } & \text { Air } \\
\text { 3. Kayu } \\
\text { 4. Daun }\end{array}$ & 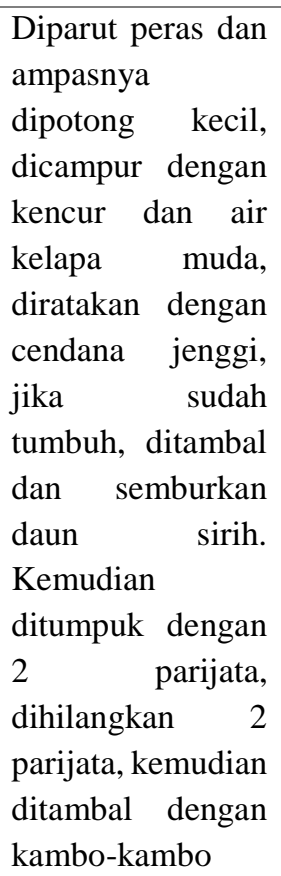 & - \\
\hline Obat bengkak & 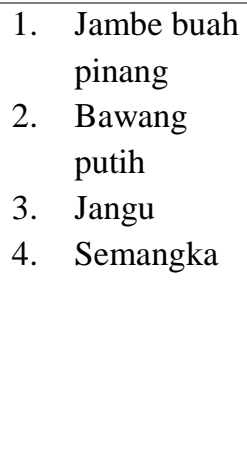 & $\begin{array}{l}\text { 1. Buah } \\
\text { 2. Umbi lapis } \\
\text { 3. Rimpang }\end{array}$ & $\begin{array}{l}\text { Disemburkan } \\
\text { dengan kotoran } \\
\text { subatah, beras } \\
\text { merah dan yang } \\
\text { dioleskan, } \\
\text { dikeringkan, } \\
\text { dicampur dengan } \\
\text { mata air yang } \\
\text { keluar dari batu } \\
\text { karang. }\end{array}$ & - \\
\hline $\begin{array}{l}\text { Obat cacar } \\
\text { sebelum sakit }\end{array}$ & $\begin{array}{l}\text { 1. } \text { Bawang } \\
\text { merah } \\
\text { 2. } \text { Beras }\end{array}$ & $\begin{array}{l}\text { 1. Umbi lapis } \\
\text { 2. Biji }\end{array}$ & $\begin{array}{l}\text { Dibedakkan, } \\
\text { dibasuh dengan } \\
\text { air di pane (priuk) } \\
\text { yang baru, } \\
\text { selanjutnya } \\
\text { dirajah }\end{array}$ & $\begin{array}{lr}\text { Ong } & \text { brahmà } \\
\text { hurung, } & \text { sarwwa } \\
\text { hurung } & \text { gring } \\
\text { hurung, bràhmà } \\
\text { sirép, 2, Ung } \\
\text { tumbah putih mtu } \\
\text { ring walang, mtu } \\
\text { wurung, 3. }\end{array}$ \\
\hline
\end{tabular}




\begin{tabular}{|c|c|c|c|c|c|}
\hline $\begin{array}{l}\text { Jika sakit } \\
\text { matanya merah }\end{array}$ & 1. & $\begin{array}{l}\text { Bawang } \\
\text { merah }\end{array}$ & 1. Umbi & $\begin{array}{l}\text { Diteteskan dan } \\
\text { dicolekkan pada } \\
\text { bagian kelopak } \\
\text { matanya dengan } \\
\text { minyak itu }\end{array}$ & $\begin{array}{l}\text { Brahmà hurung, } \\
\text { tutugaknà }\end{array}$ \\
\hline $\begin{array}{l}\text { Jika sakit } \\
\text { matanya } \\
\text { berwarna putih }\end{array}$ & 1. & $\begin{array}{l}\text { Bawang } \\
\text { putih }\end{array}$ & 1. Umbi & $\begin{array}{l}\text { Diteteskan dan } \\
\text { dicolekkan pada } \\
\text { bagian kelopak } \\
\text { matanya dengan } \\
\text { minyak itu }\end{array}$ & $\begin{array}{l}\text { Brahmà hurung, } \\
\text { tutugaknà }\end{array}$ \\
\hline $\begin{array}{l}\text { Jika sakit dan } \\
\text { membengkak di } \\
\text { lidah/kerongko } \\
\text { ngan }\end{array}$ & 1. & $\begin{array}{l}\text { Lombok } \\
\text { rambat }\end{array}$ & 1. Buah & $\begin{array}{lr}\text { Lombok } & \text { rambat } \\
\text { digoreng } & \text { tanpa } \\
\text { minyak, } & \text { itu } \\
\text { kemudian } & \text { diberi } \\
\text { minyak. } & \end{array}$ & - \\
\hline \multirow[t]{2}{*}{$\begin{array}{l}\text { Jika pecahnya } \\
\text { kemudian } \\
\text { berbintul } \\
\text { merah }\end{array}$} & $\begin{array}{l}1 . \\
2 .\end{array}$ & $\begin{array}{l}\text { Sirih } \\
\text { Lombok } \\
\text { rambat } \\
\text { Merica }\end{array}$ & $\begin{array}{ll}\text { 1. Daun yang sudah } \\
\text { tua } \\
\text { 2. Buah } \\
\text { 3. Biji }\end{array}$ & $\begin{array}{l}\text { Disemburkan } \\
\text { dengan daun sirih } \\
\text { yang sudah tua, } \\
\text { lombok rambat } \\
\text { digoreng tanpa } \\
\text { minyak ran } \\
\text { merica }\end{array}$ & $\begin{array}{l}\text { Ong syak sakti ya } \\
\text { namah swaha, } \\
\text { déwa sakti ya } \\
\text { namah swahà } \\
\text { bayu langgeng } \\
\text { awurip, Ong taya } \\
\text { ya nama swàha. }\end{array}$ \\
\hline & $\begin{array}{l}1 . \\
2 . \\
3 .\end{array}$ & $\begin{array}{l}\text { Terong } \\
\text { Bawang } \\
\text { Daun } \\
\text { dalungdung }\end{array}$ & $\begin{array}{ll}\text { 1. } & \text { Akar } \\
\text { 2. Induk bawang } \\
\text { 3. Daun }\end{array}$ & $\begin{array}{l}\text { Ditambal dengan } \\
\text { daun dalungdung, } \\
\text { induk bawang, } \\
\text { sedikit garam. }\end{array}$ & - \\
\hline $\begin{array}{l}\text { Obat cacar } \\
\text { yang dimakan }\end{array}$ & $\begin{array}{l}1 . \\
2 .\end{array}$ & $\begin{array}{l}\text { Pisang saba } \\
\text { Beras merah }\end{array}$ & $\begin{array}{l}\text { 1. Umbi } \\
\text { 2. } \text { Biji }\end{array}$ & $\begin{array}{l}\text { Diasapkan dengan } \\
\text { menaruhnya pada } \\
\text { abu api yang } \\
\text { masih panas, } \\
\text { setelah matang } \\
\text { diparut, diisi } \\
\text { dengan asam } \\
\text { kental, } \\
\text { dipanggang } \\
\text { kemudian diberi } \\
\text { beras merah }\end{array}$ & - \\
\hline $\begin{array}{l}\text { Jika terkena } \\
\text { cacar kembali }\end{array}$ & $\begin{array}{l}1 . \\
2 .\end{array}$ & $\begin{array}{l}\text { Ketumbar } \\
\text { Kacang } \\
\text { hijau }\end{array}$ & $\begin{array}{l}\text { 1. Buah } \\
\text { 2. Biji }\end{array}$ & $\begin{array}{l}\text { Anak ditutup } \\
\text { dengan sangkar, } \\
\text { kemudian suruh ia } \\
\text { memakan } \\
\text { ketumbar, ditaburi } \\
\text { di atas sangkar itu } \\
\text { dan kacang ijo } \\
\text { yang digoreng } \\
\text { tanpa minyak, } \\
\text { dimakan } 3 \text { kali, } \\
\text { sisanya ditabur di }\end{array}$ & $\begin{array}{lr}\text { Ong dadwuhan } \\
\text { kacang } \quad \text { ijo } \\
\text { pinangan, lamun } \\
\text { mentik kacang ijo } \\
\text { pinangan, kna } \\
\text { inghulun ri } \\
\text { dadawuhan } \\
\text { kacacar, lamun } \\
\text { tan } \quad \text { mentik } \\
\text { kacang } r \text { ijo } \\
\text { pinangan, } \\
\text { tan tua }\end{array}$ \\
\hline
\end{tabular}




\begin{tabular}{|c|c|c|c|c|}
\hline & & & $\begin{array}{l}\text { tempat tidur, dan } \\
\text { di halaman rumah }\end{array}$ & $\begin{array}{l}\text { nghulun ring } \\
\text { dadawuhan } \\
\text { kacacar, bhìmà. }\end{array}$ \\
\hline $\begin{array}{l}\text { Obat cacar jika } \\
\text { pecah batunya }\end{array}$ & $\begin{array}{ll}\text { 1. } & \text { Sirih } \\
\text { 2. } & \text { Bawang } \\
& \text { putih } \\
\text { 3. } & \text { Jangu } \\
\text { 4. } & \text { Lombok } \\
& \text { rambat }\end{array}$ & $\begin{array}{l}\text { 1. Daun yang sudah } \\
\text { tua } \\
\text { 2. Umbi } \\
\text { 3. Batang } \\
\text { 4. Buah }\end{array}$ & $\begin{array}{ll}\text { Semua } & \text { itu } \\
\text { disemburkan. }\end{array}$ & - \\
\hline $\begin{array}{l}\text { Pengompresan } \\
\text { cacar }\end{array}$ & $\begin{array}{ll}\text { 1. } & \text { Kulit } \\
& \text { kaloncing } \\
\text { 2. } & \text { Lengkuas } \\
\text { 3. } & \text { Sirih } \\
\text { 4. } & \text { Cendana }\end{array}$ & $\begin{array}{ll}\text { 1. } & \text { Kulit } \\
\text { 2. } & \text { Rimpang } \\
\text { 3. } & \text { Daun } \\
\text { 4. } & \text { Kayu }\end{array}$ & $\begin{array}{l}\text { Dimandikan } \\
\text { sebanyak } 2 \text { kali } \\
\text { pada badannya } \\
\text { dengan } \\
\text { mencampurkan } \\
\text { airnya dengan } 2 \\
\text { lawos, } \quad \text { dan } \\
\text { candana yang } \\
\text { digosok. }\end{array}$ & - \\
\hline $\begin{array}{l}\text { Cacar yang } \\
\text { disemburkan }\end{array}$ & $\begin{array}{ll}\text { 1. } & \text { Lengkuas } \\
\text { 2. } & \text { Rumput teki } \\
\text { 3. } & \text { Gamongan } \\
\text { 4. } & \text { Jebug arum } \\
\text { 5. } & \text { Sirih } \\
\end{array}$ & $\begin{array}{ll}\text { 1. } & \text { Rimpang } \\
\text { 2. } & \text { Umbi } \\
\text { 3. } & \text { Umbi } \\
\text { 4. } & \text { Buah } \\
\text { 5. } & \text { Daun yang tua }\end{array}$ & $\begin{array}{l}\text { Semua bahan } \\
\text { dicincang } \\
\text { kemudian } \\
\text { disemburkan pada } \\
\text { cacar }\end{array}$ & - \\
\hline \multirow[t]{2}{*}{ Obat lalodok } & $\begin{array}{ll}\text { 1. } & \text { Dadap } \\
\text { 2. } & \text { Sempol } \\
\text { 3. } & \text { Pulasahi } \\
\text { 4. } & \text { Kemiri }\end{array}$ & $\begin{array}{ll}\text { 1. } & \text { Daun } \\
\text { 2. } & \text { Bunga } \\
\text { 3. } & \text { Akar } \\
\text { 4. } & \text { Buah }\end{array}$ & $\begin{array}{l}\text { Semua bahan } \\
\text { diasapkan dengan } \\
\text { menaruhnya pada } \\
\text { abu api yang } \\
\text { masih panas, } \\
\text { semua dihaluskan } \\
\text { kemudian dadah. }\end{array}$ & - \\
\hline & $\begin{array}{ll}\text { 1. } & \text { Kepuh } \\
\text { 2. } & \text { Daun } \\
& \text { canging } \\
\text { 3. } & \text { Sari lungid } \\
\text { 4. } & \text { Cendana }\end{array}$ & $\begin{array}{ll}\text { 1. } & \text { Blah bosok } \\
\text { 2. } & \text { Daun } \\
\text { 3. } & - \\
\text { 4. } & \text { Kayu }\end{array}$ & $\begin{array}{l}\text { Dioleskan atau } \\
\text { dibedakkan } \\
\text { badan }\end{array}$ & - \\
\hline $\begin{array}{l}\text { Cacar yang } \\
\text { pecah }\end{array}$ & $\begin{array}{ll}\text { 1. } & \text { Dadap } \\
\text { 2. } & \text { Ketumbar } \\
\text { 3. } & \text { Lengkuas } \\
\text { 4. } & \text { Kemiri }\end{array}$ & $\begin{array}{ll}\text { 1. } & \text { Daun yang } \\
\text { kering } \\
\text { 2. Buah } \\
\text { 3. Rimpang } \\
\text { 4. Daging buah }\end{array}$ & $\begin{array}{l}\text { Semua bahan } \\
\text { dicampurkan } \\
\text { dengan kemiri } \\
\text { yang digoreng } \\
\text { tanpa minyak, } \\
\text { kemudian } \\
\text { disemburkan pada } \\
\text { cacar yang pecah. }\end{array}$ & - \\
\hline $\begin{array}{l}\text { Obat kutiken } \\
\text { puwuh }\end{array}$ & $\begin{array}{l}\text { Kelapa } \\
\text { kuning } \\
\text { (muda) }\end{array}$ & 1. Air kelapa & $\begin{array}{l}\text { Dipotong dengan } \\
\text { membentuk tiga } \\
\text { siku, direbus } \\
\text { sampai mendidih. } \\
\text { Ketika merebus }\end{array}$ & $\begin{array}{l}\text { Plalukatan, } \\
\text { siranak paduka } \\
\text { Bhatàra Hyang } \\
\text { kaki, tutugakna. }\end{array}$ \\
\hline
\end{tabular}




\begin{tabular}{|c|c|c|c|c|}
\hline & & & $\begin{array}{l}\text { diisi dengan } \\
\text { lebwani } \\
\text { kemenyan madu. }\end{array}$ & \\
\hline & $\begin{array}{ll}\text { 1. } & \text { Jambe } \\
\text { 2. Jebug } \\
\text { 3. }\end{array}$ & $\begin{array}{l}\text { 1. } \text { Buah } \\
\text { 2. Buah } \\
\text { 3. } \text { Daun }\end{array}$ & $\begin{array}{l}\text { Jambe dan jebug } \\
\text { digoreng tanpa } \\
\text { minyak, } \\
\text { ditambahkan } \\
\text { bahan lainnya } \\
\text { kemudian } \\
\text { disemburkan pada } \\
\text { punggungnya. }\end{array}$ & - \\
\hline $\begin{array}{l}\text { Jika bibirnya } \\
\text { pecah-pecah }\end{array}$ & $\begin{array}{ll}\text { 1. } & \text { Dadap } \\
\text { 2. } & \text { Bawang } \\
\text { 3. } & \text { Kemiri }\end{array}$ & $\begin{array}{ll}\text { 1. } & \text { Embong } \\
\text { 2. } & \text { Daging } \\
\text { 3. } & \text { Buah }\end{array}$ & $\begin{array}{l}\text { Semuanya diulek, } \\
\text { dibubuhi dengan } \\
\text { kemiri } \\
\text { dihangatkan, } \\
\text { oleskan pada } \\
\text { bibirnya yang } \\
\text { pecah. }\end{array}$ & - \\
\hline $\begin{array}{l}\text { Obat cacar jika } \\
\text { perutnya terasa } \\
\text { sakit }\end{array}$ & $\begin{array}{ll}\text { 1. } & \text { Bawang } \\
\text { putih } \\
\text { 2. Jaringau } \\
\text { 3. Lasowi }\end{array}$ & $\begin{array}{ll}\text { 1. } & \text { Daging } \\
\text { 2. } & \text { Batang } \\
\text { 3. } & -\end{array}$ & $\begin{array}{l}\text { Semua } \\
\text { dilumatkan, } \\
\text { ditaruh pada perut } \\
\text { bagian tengah. }\end{array}$ & $\begin{array}{l}\text { Ong puuh sukun, } \\
\text { puwuh balulang, } \\
\text { puwuh nasi wruh } \\
\text { sip o ko saking } \\
\text { maloki, rep ta } \\
\text { ngko dengku } \\
\text { (Mantra yang } \\
\text { digunakan ketika } \\
\text { memandikan } \\
\text { orang yang sakit } \\
\text { cacar, priuknya } \\
\text { dirajah dengan } \\
\text { mantra : Ong } \\
\text { sùkûma nirmmlà, } \\
\text { nirpapà, nir } \\
\text { upadrawa, tirthà } \\
\text { pawitra jati ya } \\
\text { namah swahà.) }\end{array}$ \\
\hline $\begin{array}{l}\text { Obat cacar } \\
\text { apabila ia } \\
\text { terlihat buruk }\end{array}$ & $\begin{array}{ll}\text { 1. } & \text { Kayu skang } \\
\text { 2. } & \text { Liligundi } \\
\text { 3. } & \text { Lombok } \\
& \text { rambat }\end{array}$ & $\begin{array}{l}\text { 1. Belahan kayu } \\
\text { 2. Daun } \\
\text { 3. Buah }\end{array}$ & $\begin{array}{l}\text { Belahan kayu } \\
\text { skang, } 2 \text { liligundi, } \\
\text { ditutup dengan } \\
\text { kain. Bahan lain } \\
\text { disemburkan, } \\
\text { lombok rambat } \\
\text { digoreng tanpa } \\
\text { minyak. }\end{array}$ & $\begin{array}{l}\text { Brahmà wurung } \\
\text { tutugakna. }\end{array}$ \\
\hline $\begin{array}{l}\text { Jika pecah- } \\
\text { pecah, dan jika } \\
\text { ia luka yang } \\
\text { cukup besar }\end{array}$ & $\begin{array}{ll}\text { 1. } & \text { Kacemcem } \\
\text { 2. } & \text { Buhu } \\
\text { 3. } & \text { Cengkeh } \\
\text { 4. Jebugarum }\end{array}$ & $\begin{array}{ll}\text { 1. } & \text { Kulit } \\
\text { 2. } & \text { Kulit } \\
\text { 3. } & \text { Tangkai } \\
\text { 4. } & \text { Buah }\end{array}$ & $\begin{array}{l}\text { Dibakar, diulek, } \\
\text { dicampurkan } \\
\text { semua } \\
\text { dilumatkan, }\end{array}$ & - \\
\hline
\end{tabular}




\begin{tabular}{|c|c|c|c|c|c|}
\hline $\begin{array}{l}\text { besar, merasa } \\
\text { gatal }\end{array}$ & $\begin{array}{l}5 . \\
6 .\end{array}$ & $\begin{array}{l}\text { Ketumbar } \\
\text { bolong } \\
\text { Lombok } \\
\text { rambat } \\
\text { Buah } \\
\text { badung }\end{array}$ & $\begin{array}{ll}\text { 5. } & \text { Buah } \\
\text { 6. } & \text { Buah } \\
\text { 7. } & \text { Daging buah }\end{array}$ & $\begin{array}{l}\text { dihangatkan } \\
\text { kemudian } \\
\text { dioleskan. }\end{array}$ & \\
\hline $\begin{array}{l}\text { Jika puuh } \\
\text { alintah }\end{array}$ & $\begin{array}{l}1 . \\
2 . \\
3 .\end{array}$ & $\begin{array}{l}\text { Kulit sigru } \\
\text { Bawang } \\
\text { putih } \\
\text { Jaringau }\end{array}$ & $\begin{array}{ll}\text { 1. } & \text { Kulit } \\
\text { 2. } & \text { Daging } \\
\text { 3. } & \text { Batang }\end{array}$ & $\begin{array}{l}\text { Semua bahan } \\
\text { dipotong kecil dan } \\
\text { dibubuhi kapur } \\
\text { sirih, kemudian } \\
\text { dioleskan. }\end{array}$ & - \\
\hline $\begin{array}{l}\text { Jika puuh } \\
\text { daluwang }\end{array}$ & $\begin{array}{l}1 . \\
2 . \\
3 . \\
4 .\end{array}$ & $\begin{array}{l}\text { Lengkuas } \\
\text { Jebugarum } \\
\text { Merica } \\
\text { Lombok } \\
\text { rambat } \\
\text { Sirih }\end{array}$ & $\begin{array}{l}\text { 1. Rimpang } \\
\text { 2. Daging buah } \\
\text { 3. Buah } \\
\text { 4. Daging buah } \\
\text { 5. Daun yang tua }\end{array}$ & $\begin{array}{l}\text { Diparut kemudian } \\
\text { diperas } \\
\text { dicampurkan } \\
\text { dengan } \\
\text { jebugarum, } \\
\text { merica, lombok } \\
\text { rambat digoreng } \\
\text { tanpa minyak, dan } \\
\text { juga air sirih, } \\
\text { kemudian } \\
\text { disemburkan. }\end{array}$ & $\begin{array}{l}\text { Ong bhatàra } \\
\text { Brahmà ndadi } \\
\text { gtih, bhatarà } \\
\text { Wisnu dadi gtih, } \\
\text { kurapaglap kilap, } \\
\text { magawe puwuh, } \\
\text { syah. }\end{array}$ \\
\hline $\begin{array}{l}\text { Jika sudah } \\
\text { selesai } \\
\text { membersihkan } \\
\text { nya }\end{array}$ & $\begin{array}{l}1 . \\
2 . \\
3 . \\
4 . \\
5 .\end{array}$ & $\begin{array}{l}\text { Liligundi } \\
\text { Gamongan } \\
\text { Lengkuas } \\
\text { Jebugarum } \\
\text { Sampar } \\
\text { wantu } \\
\text { Ketumbar } \\
\text { Glam } \\
\text { kemiri }\end{array}$ & $\begin{array}{l}\text { 1. } \\
\text { 2. Uaun } \\
\text { 3. Rimpi } \\
\text { 4. } \\
\text { 5. } \\
\text { 6. } \\
\text { 7. } \\
\text { Buahing buah } \\
\text { 8. } \\
\text { Buah }\end{array}$ & Dibedakkan & - \\
\hline $\begin{array}{l}\text { Obat sakit yang } \\
\text { membengkak }\end{array}$ & $\begin{array}{l}1 . \\
2 . \\
3 . \\
4 . \\
5 .\end{array}$ & $\begin{array}{l}\text { Lampeni } \\
\text { Kambo- } \\
\text { kambo } \\
\text { Lengkuas } \\
\text { Ketumbar } \\
\text { Sampar } \\
\text { wantu }\end{array}$ & $\begin{array}{ll}\text { 1. } & \text { Kulit } \\
\text { 2. } & \text { Buah } \\
\text { 3. } & \text { Rimpang } \\
\text { 4. } & \text { Buah } \\
\text { 5. } & -\end{array}$ & Dioleskan & $\begin{array}{l}\text { Konci rapet } \\
\text { lawang alah, } \\
\text { nghisa rapet } \\
\text { lawang alah, } \\
\text { alah. }\end{array}$ \\
\hline \multirow[t]{2}{*}{$\begin{array}{l}\text { Jika } \\
\text { pecahannya } \\
\text { terasa tebal dan } \\
\text { dingin (jangan } \\
\text { dimandikan) }\end{array}$} & $\begin{array}{l}1 . \\
2 . \\
3 . \\
4 . \\
5 .\end{array}$ & $\begin{array}{l}\text { Sirih } \\
\text { Lampuyang } \\
\text { Lengkuas } \\
\text { Kencur } \\
\text { Lombok } \\
\text { rambat } \\
\text { Kelapa }\end{array}$ & $\begin{array}{l}\text { 1. Daun yang tua } \\
\text { 2. Rimpang } \\
\text { 3. Rimpang } \\
\text { 4. Rimpang } \\
\text { 5. Daging buah } \\
\text { 6. Daging buah }\end{array}$ & $\begin{array}{l}\text { Dibakar kemudian } \\
\text { dikerik, kemudian } \\
\text { dipetis, supaya } \\
\text { tidak gatal, dan } \\
\text { mengencang, } \\
\text { kemudian } \\
\text { disemburkan. }\end{array}$ & - \\
\hline & & $\begin{array}{l}\text { Sembung } \\
\text { Pare } \\
\text { Beras }\end{array}$ & $\begin{array}{ll}\text { 1. } & \text { Kayu } \\
\text { 2. } & \text { Kayu yang } \\
\text { pecah }\end{array}$ & $\begin{array}{l}\text { Sembung, pare } \\
\text { dan beras } \\
\text { direndam, bawang }\end{array}$ & \\
\hline
\end{tabular}




\begin{tabular}{|c|c|c|c|c|}
\hline & 4. Bawang & $\begin{array}{ll}\text { 3. } & \text { Buah } \\
\text { 4. } & \text { Daging }\end{array}$ & $\begin{array}{l}\text { ditaruh di dalam } \\
\text { abu yang masih } \\
\text { panas, kemudian } \\
\text { dibalurkan dengan } \\
\text { air beras. }\end{array}$ & \\
\hline $\begin{array}{l}\text { Obat cacar jika } \\
\text { gatal }\end{array}$ & $\begin{array}{ll}\text { 1. } & \text { Brotowali } \\
\text { 2. } & \text { Pare } \\
\text { 3. } & \text { Badung } \\
\text { 4. } & \text { Asam } \\
\text { 5. } & \text { Kacicang } \\
\text { 6. } & \text { Ampo } \\
\text { 7. } & \text { Cendana }\end{array}$ & $\begin{array}{ll}\text { 1. } & \text { Daun } \\
\text { 2. Daun } \\
\text { 3. } \\
\text { Buah kering yang } \\
\text { 4. Daging buah } \\
\text { 5. Umbi } \\
\text { 6. - } \\
\text { 7. Kayu }\end{array}$ & $\begin{array}{lr}\text { Semua bahan } \\
\text { ditumbuk, direbus } \\
\text { sampai matang, } \\
\text { tambahkan } \\
\text { dengan air } \\
\text { cendana harum } \\
\text { kemudian } \\
\text { balurkan semasih } \\
\text { hangat kuku, } \\
\text { tambal di tempat } \\
\text { yang gatal, } \\
\text { dengan tangan } \\
\text { ditempelkan. }\end{array}$ & - \\
\hline $\begin{array}{l}\text { Setelah } \\
\text { gatalnya mulai } \\
\text { hilang }\end{array}$ & $\begin{array}{ll}\text { 1. } & \text { Sirih } \\
\text { 2. } & \text { Liligundi } \\
\text { 3. } & \text { Dadap } \\
\text { 4. } & \text { Gamongan } \\
\text { 5. Ketumbar } \\
\text { 6. Jebugarum } \\
\text { 7. Sàmparwant } \\
\quad u \\
\text { 8. } \text { Bawang } \\
\text { putih } \\
\text { 9. Jaringau } \\
\text { 10. Kemiri } \\
\text { 11. Merica } \\
\text { 12. Lombok } \\
\text { rambat } \\
\text { 13. Jeruk } \\
\text { linglang }\end{array}$ & $\begin{array}{l}\text { 1. Daun yang tua } \\
\text { 2. Daun } \\
\text { 3. Daun } \\
\text { 4. Umbi } \\
\text { 5. Buah } \\
\text { 6. Daging buah } \\
\text { 7. Umbi lapis } \\
\text { 8. Umbi } \\
\text { 9. Batang } \\
\text { 10. Buah } \\
\text { 11. Buah } \\
\text { 12. Daging buah } \\
\text { 13. Buah }\end{array}$ & $\begin{array}{l}\text { Dicampurkan, } \\
\text { dibedakkan } \\
\text { (dibalurkan). } \\
\text { Sebagai usug, } \\
\text { gamongan, } \\
\text { kàtambah, } \\
\text { bawang putih } \\
\text { jangu, kemiri } \\
\text { mentah, } 3 \text { merica, } \\
3 \text { lombok rambat, } \\
\text { santan, airnya } \\
\text { jeruk linglang, } \\
\text { dimasak sampai } \\
\text { matang. }\end{array}$ & - \\
\hline $\begin{array}{l}\text { Obat jika } \\
\text { njarem }\end{array}$ & $\begin{array}{ll}\text { 1. } & \text { Sirih } \\
\text { 2. } & \text { Gamongan } \\
\text { 3. } & \text { Asam }\end{array}$ & $\begin{array}{ll}\text { 1. } & \text { Daun yang tua } \\
\text { 2. Umbi } \\
\text { 3. }\end{array}$ & $\begin{array}{l}\text { Semua bahan } \\
\text { dilumatkan } \\
\text { sampai lembut, } \\
\text { dioleskan. }\end{array}$ & Мауири \\
\hline $\begin{array}{lr}\text { Jika } & \text { terasa } \\
\text { panas } & \text { karena } \\
\text { cacar } & \\
\end{array}$ & $\begin{array}{ll}\text { 1. } & \text { Sirih } \\
\text { 2. } & \text { Bawang } \\
& \text { putih } \\
\text { 3. } & \text { Jangu } \\
\text { 4. } & \text { Masui } \\
\text { 5. } & \text { Merica }\end{array}$ & $\begin{array}{ll}\text { 1. } & \text { Daun tua } \\
\text { 2. } & \text { Umbi } \\
\text { 3. } & \text { Batang } \\
\text { 4. } & \text { Kulit batang } \\
\text { 5. } & \text { Buah }\end{array}$ & $\begin{array}{l}\text { Disemburkan } \\
\text { pada bagian yang } \\
\text { panas. }\end{array}$ & $\begin{array}{l}\text { Ong Sanghyang } \\
\text { Mandiràksa, } \\
\text { tutugakna. }\end{array}$ \\
\hline $\begin{array}{l}\text { Jika matanya } \\
\text { berwarna }\end{array}$ & $\begin{array}{ll}\text { 1. } & \text { Caremen } \\
\text { 2. } & \text { Belimbing } \\
\text { besi }\end{array}$ & $\begin{array}{l}\text { 1. Buah } \\
\text { 2. Buah }\end{array}$ & $\begin{array}{l}\text { Dihancurkan } \\
\text { banyoni wrak, } \\
\text { kemudian }\end{array}$ & \\
\hline
\end{tabular}




\begin{tabular}{|c|c|c|c|c|}
\hline $\begin{array}{l}\text { merah dan } \\
\text { membengkak }\end{array}$ & & & $\begin{array}{l}\text { dibedakkan pada } \\
\text { bagian luar. }\end{array}$ & \\
\hline $\begin{array}{l}\text { Obat } \\
\text { pangaduhan }\end{array}$ & $\begin{array}{ll}\text { 1. } & \text { Sirih } \\
\text { 2. } & \text { Cabe } \\
\text { 3. } & \text { Bawang } \\
\text { merah } \\
\text { 4. } & \text { Bawang } \\
\text { putih } \\
\text { 5. Jangu }\end{array}$ & $\begin{array}{ll}\text { 1. } & \text { Daun tua } \\
\text { 2. } & \text { Daging buah } \\
\text { 3. Umbi } \\
\text { 4. Umbi } \\
\text { 5. } & \text { Batang }\end{array}$ & $\begin{array}{l}\text { Dilumatkan, air } \\
\text { ludah merah, } \\
\text { kemudian } \\
\text { dioleskan. }\end{array}$ & - \\
\hline $\begin{array}{l}\text { Jika cacar } \\
\text { membengkak } \\
\text { disetiap } \\
\text { persendian }\end{array}$ & $\begin{array}{l}\text { 1. Beras merah } \\
\text { 2. Lengkuas }\end{array}$ & $\begin{array}{ll}\text { 1. } & \text { Buah } \\
\text { 2. Rimpang }\end{array}$ & Disemburkan. & - \\
\hline $\begin{array}{l}\text { Obat cacar jika } \\
\text { terasa tebal, } \\
\text { pecah seperti } \\
\text { borok }\end{array}$ & $\begin{array}{ll}\text { 1. } & \text { Sirih } \\
\text { 2. } & \text { Lengkuas } \\
\text { 3. } & \text { Beras } \\
\text { 4. } & \text { Gamongan } \\
\text { 5. } & \text { Kencur }\end{array}$ & $\begin{array}{ll}\text { 1. } & \text { Daun tua } \\
\text { 2. } & \text { Rimpang } \\
\text { 3. } & \text { Buah } \\
\text { 4. Umbi } \\
\text { 5. }\end{array}$ & $\begin{array}{l}\text { Dipotong kecil- } \\
\text { kecil, diparut dan } \\
\text { kemudian diperas, } \\
\text { cari sarinya, air } \\
\text { beras, dibubuhi } \\
\text { bawang yang } \\
\text { dilumatkan, sama } \\
\text { besarnya air beras, } \\
\text { akar lengkuas itu } \\
\text { diamkan, buncal } \\
\text { sagu, gamongan } \\
\text { krayan kencur, } \\
\text { diparut dan } \\
\text { diperas, akarnya } \\
\text { dibuang, semua } \\
\text { ampasnya } \\
\text { dibubuhkan pada } \\
\text { daun sirih tua, } \\
\text { disemburkan pada } \\
\text { cacar itu, setelah } \\
\text { mandi, } \\
\text { disemburkan lagi, } \\
\text { jangan sampai } \\
\text { dingin. }\end{array}$ & - \\
\hline $\begin{array}{ll}\text { Cacar } & \text { disertai } \\
\text { sakit } & \text { disetiap } \\
\text { sendi } & \end{array}$ & 1. Kunyit & 1. Rimpang & Disemburkan. & - \\
\hline $\begin{array}{l}\text { Jika tidak sakit } \\
\text { pada perutnya }\end{array}$ & $\begin{array}{l}\text { 1. } \text { Bawang } \\
\text { putih } \\
\text { 2. Jangu/jaring } \\
\text { au }\end{array}$ & $\begin{array}{ll}\text { 1. Umbi } \\
\text { 2. } & \text { Batang }\end{array}$ & $\begin{array}{l}\text { Diletakkan pada } \\
\text { pusar. }\end{array}$ & - \\
\hline $\begin{array}{l}\text { Obat yang } \\
\text { dioleskan } \\
\text { papuwuhe }\end{array}$ & $\begin{array}{l}\text { 1. Lengkuas } \\
\text { 2. Cendana }\end{array}$ & $\begin{array}{l}\text { 1. Rimpang } \\
\text { 2. Kayu }\end{array}$ & $\begin{array}{l}\text { Semua } \\
\text { dilumatkan, } \\
\text { tambahkan }\end{array}$ & - \\
\hline
\end{tabular}




\begin{tabular}{|c|c|c|c|c|}
\hline$\frac{\text { kàwon }}{\text { gatal }}$ & & & $\begin{array}{l}\text { dengan air cuka, } \\
\text { dioleskan pada } \\
\text { tempat yang sakit } \\
\text { dan gatal. }\end{array}$ & \\
\hline $\begin{array}{lr}\text { Jika } & \text { selesai } \\
\text { ditekan, } & \text { dan } \\
\text { terasa } & \text { sakit } \\
\text { serta bengkak }\end{array}$ & $\begin{array}{ll}\text { 1. } & \text { Dadap } \\
\text { 2. } & \text { Kelapa } \\
& \text { sinaga } \\
\text { 3. } & \text { Sirih }\end{array}$ & $\begin{array}{ll}\text { 1. } & \text { Kulit kayu } \\
\text { 2. } & \text { Kulit kelapa } \\
\text { 3. } & \text { Daun tua }\end{array}$ & $\begin{array}{l}\text { Semua dicampur } \\
\text { dengan daging } \\
\text { rong, } \\
\text { disemburkan pada } \\
\text { tempat yang sakit } \\
\text { dan pada tempat } \\
\text { yang bengkak. }\end{array}$ & - \\
\hline $\begin{array}{l}\text { Jika pecahnya } \\
\text { memerah }\end{array}$ & $\begin{array}{ll}\text { 1. } & \text { Pare } \\
\text { 2. Ketumbar }\end{array}$ & $\begin{array}{ll}\text { 1. } & \text { Puh } \\
\text { 2. } & \text { Buah }\end{array}$ & $\begin{array}{l}\text { Semua } \\
\text { dihaluskan, } \\
\text { tambahkan air } \\
\text { cuka, oleskan } \\
\text { pada cacar yang } \\
\text { pecah itu, } \\
\text { celupkan. }\end{array}$ & - \\
\hline $\begin{array}{l}\text { Obat mata yang } \\
\text { saputen }\end{array}$ & $\begin{array}{l}\text { 1. Jagung putih } \\
\text { 2. Bawang }\end{array}$ & $\begin{array}{ll}\text { 1. } & \text { Biji } \\
\text { 2. } & \text { Umbi }\end{array}$ & \begin{tabular}{lr}
\multicolumn{2}{l}{ Ditempatkan pada } \\
tempat mandi \\
yang hitam, diisi \\
dengan air, \\
masukkan bawang \\
jagung itu \\
semalam, sampai \\
selesai.
\end{tabular} & - \\
\hline $\begin{array}{ll}\text { Obat } & \text { tidak } \\
\text { kawaúa } & \text { ngléd } \\
(\text { dimakan }) / \text { Luk } \\
\text { a cacar menjadi } \\
\text { borok }\end{array}$ & $\begin{array}{ll}\text { 1. } & \text { Kemiri } \\
\text { 2. } & \text { Adas } \\
\text { 3. } & \text { Paparé } \\
& \text { ambulungan }\end{array}$ & $\begin{array}{ll}\text { 1. } & \text { Buah } \\
\text { 2. } & \text { Buah } \\
\text { 3. } & -\end{array}$ & $\begin{array}{l}\text { Dibakar, adas, } \\
\text { dilumatkan, } \\
\text { kemudian } \\
\text { dibalurkan. }\end{array}$ & - \\
\hline $\begin{array}{l}\text { Obat cacar jika } \\
\text { tidak terasa apa } \\
\text { ketika dipegang }\end{array}$ & $\begin{array}{ll}\text { 1. } & \text { Kasimbukan } \\
\text { 2. } & \text { Mer } \\
\text { 3. } & \text { Pandan } \\
\text { 4. } & \text { Teki }\end{array}$ & $\begin{array}{ll}\text { 1. } & \text { Akar daun } \\
\text { 2. } & \text { Daun } \\
\text { 3. } & \text { Mbotan } \\
\text { 4. } & \text { Mbotan }\end{array}$ & $\begin{array}{l}\text { Semua } \\
\text { dihaluskan, } \\
\text { campur dengan } \\
\text { ginten sebanyak 7, } \\
\text { balurkan pada } \\
\text { bokongnya. }\end{array}$ & - \\
\hline $\begin{array}{l}\text { Obat cacar jika } \\
\text { mengeluarkan } \\
\text { darah }\end{array}$ & $\begin{array}{ll}\text { 1. } & \text { Kasine } \\
\text { 2. } & \text { Bawang } \\
\text { 3. } & \text { Adas }\end{array}$ & $\begin{array}{ll}\text { 1. } & \text { Daun } \\
\text { 2. } & \text { Umbi } \\
\text { 3. } & \text { Buah }\end{array}$ & $\begin{array}{lr}\text { Semua } & \text { bahan } \\
\text { disemburkan pada } \\
\text { dadanya } & \text { sampai } \\
\text { pada } & \text { pangkal } \\
\text { lehernya. } & \\
\end{array}$ & - \\
\hline $\begin{array}{l}\text { Obat cacar jika } \\
\text { ia ngising }\end{array}$ & $\begin{array}{ll}\text { 1. } & \text { Kelapa } \\
\text { 2. } & \text { Ketumbar } \\
\text { 3. } & \text { Kunyit }\end{array}$ & $\begin{array}{ll}\text { 1. } & \text { Kulit } \\
\text { 2. } & \text { Buah } \\
\text { 3. } & \text { Rimpang }\end{array}$ & $\begin{array}{l}\text { Dihangatkan } \\
\text { (tambus) sampai } \\
\text { matang, } \\
\text { dilumatkan } \\
\text { sampai halus, } \\
\text { kemudian }\end{array}$ & - \\
\hline
\end{tabular}




\begin{tabular}{|c|c|c|c|c|}
\hline & & & $\begin{array}{l}\text { dioleskan pada } \\
\text { bokongnya. }\end{array}$ & \\
\hline & $\begin{array}{ll}\text { 1. } & \text { Melinjo } \\
\text { 2. } & \text { Jebugarum } \\
\text { 3. } & \text { Cengkeh } \\
\text { 4. } & \text { Masuwi }\end{array}$ & $\begin{array}{ll}\text { 1. } & \text { Kulit } \\
\text { 2. } & \text { Daging buah } \\
\text { 3. } & \text { Tangkai } \\
\text { 4. } & \text { Kulit batang }\end{array}$ & $\begin{array}{l}\text { Dioleskan pada } \\
\text { bokongnya. }\end{array}$ & - \\
\hline \multirow[t]{3}{*}{$\begin{array}{l}\text { Obat cacar jika } \\
\text { terasa gatal }\end{array}$} & $\begin{array}{ll}\text { 1. } & \text { Canging } \\
\text { 2. } & \text { Maduri } \\
\text { 3. } & \text { Lengkuas }\end{array}$ & $\begin{array}{ll}\text { 1. } & - \\
\text { 2. } & \text { Bunga } \\
\text { 3. } & \text { Rimpang }\end{array}$ & $\begin{array}{l}\text { Dipanggang, } \\
\text { kemudian } \\
\text { oleskan. }\end{array}$ & - \\
\hline & $\begin{array}{ll}\text { 1. } & \text { Kambo- } \\
& \text { kambo } \\
\text { 2. } & \text { Lapeni } \\
\text { 3. } & \text { Cungkaka }\end{array}$ & $\begin{array}{ll}\text { 1. } & \text { Buah } \\
\text { 2. } & \text { Buah } \\
\text { 3. } & -\end{array}$ & $\begin{array}{l}\text { Semua } \\
\text { dilumatkan, } \\
\text { dioleskan pada } \\
\text { tempat yang terasa } \\
\text { gatal. }\end{array}$ & - \\
\hline & $\begin{array}{ll}\text { 1. } & \text { Cabe } \\
\text { 2. } & \text { Kencur }\end{array}$ & $\begin{array}{l}\text { 1. Buah } \\
\text { 2. Rimpang }\end{array}$ & $\begin{array}{l}\text { Disembutkan } \\
\text { pada yang terasa } \\
\text { gatal. }\end{array}$ & - \\
\hline $\begin{array}{l}\text { Obat cacar jika } \\
\text { perut terasa } \\
\text { sakit, tidak } \\
\text { tetap sakit yang } \\
\text { dirasakan }\end{array}$ & $\begin{array}{ll}\text { 1. } & \text { Kunyit } \\
\text { 2. } & \text { Ketumbar }\end{array}$ & $\begin{array}{l}\text { 1. Rimpang } \\
\text { 2. Buah }\end{array}$ & $\begin{array}{l}\text { Disemburkan } \\
\text { pada tempat yang } \\
\text { terasa sakit. }\end{array}$ & - \\
\hline $\begin{array}{l}\text { Obat cacar jika } \\
\text { sakitnya } \\
\text { disetiap bagian }\end{array}$ & $\begin{array}{ll}\text { 1. } & \text { Kunyit } \\
\text { 2. } & \text { Bawang } \\
\text { 3. } & \text { Adas }\end{array}$ & $\begin{array}{ll}\text { 1. } & \text { Rimpang } \\
\text { 2. Umbi } \\
\text { 3. } \\
\text { Buah }\end{array}$ & $\begin{array}{l}\text { Dioleskan pada } \\
\text { tempat yang terasa } \\
\text { sakit. }\end{array}$ & - \\
\hline & $\begin{array}{ll}\text { 1. } & \text { Sirih } \\
\text { 2. } & \text { Masuwi } \\
\text { 3. } & \text { Jebug/pinan } \\
& \mathrm{g}\end{array}$ & $\begin{array}{l}\text { 1. Daun yang tua } \\
\text { 2. Kulit batang } \\
\text { 3. Buah }\end{array}$ & Dioleskan. & - \\
\hline $\begin{array}{l}\text { Obat cacar } \\
\text { jikalau mual }\end{array}$ & $\begin{array}{ll}\text { 1. } & \text { Salam } \\
\text { 2. } & \text { Ketumbar } \\
\text { 3. } & \text { Pule } \\
\text { 4. } & \text { Kunyit } \\
\text { 5. } & \text { Temu kunci } \\
\text { 6. } & \text { Kencur } \\
\text { 7. } & \text { Jebugarum }\end{array}$ & $\begin{array}{ll}\text { 1. } & \text { Daun } \\
\text { 2. } & \text { Buah } \\
\text { 3. } & \text { Kuit pohon yang } \\
& \text { kering } \\
\text { 4. } & \text { Rimpang } \\
\text { 5. } & \text { Rimpang } \\
\text { 6. } & \text { Rimpang } \\
\text { 7. } & \text { Buah }\end{array}$ & $\begin{array}{l}\text { Semburkan pada } \\
\text { ulun hati (antara } \\
\text { perut dan dada). }\end{array}$ & - \\
\hline $\begin{array}{l}\text { Obat cacar jika } \\
\text { bibirnya kering }\end{array}$ & $\begin{array}{ll}\text { 1. } & \text { Dadap } \\
\text { 2. } & \text { Kemiri } \\
\text { 3. } & \text { Jebugarum }\end{array}$ & $\begin{array}{ll}\text { 1. } & \text { Embong } \\
\text { 2. } & \text { Daging buah } \\
\text { 3. } & \text { Daging buah }\end{array}$ & $\begin{array}{l}\text { Dilumatkan } \\
\text { sampai halus, dan } \\
\text { dioleskan pada } \\
\text { bibirnya yang } \\
\text { sakit. }\end{array}$ & - \\
\hline $\begin{array}{l}\text { Obat cacar jika } \\
\text { sakit disetiap } \\
\text { bagian }\end{array}$ & $\begin{array}{ll}\text { 1. } & \text { Jahe } \\
\text { 2. } & \text { Temu hitam } \\
\text { 3. } & \text { Buah } \\
\text { badung } \\
\text { 4. } & \text { Cendana }\end{array}$ & $\begin{array}{ll}\text { 1. } & \text { Rimpang } \\
\text { 2. } & \text { Rimpang } \\
\text { 3. } & \text { Kulit } \\
\text { 4. } & \text { Bubuk kayu }\end{array}$ & $\begin{array}{l}\text { Dioleskan pada } \\
\text { tempat yang terasa } \\
\text { sakit. }\end{array}$ & - \\
\hline
\end{tabular}




\begin{tabular}{|c|c|c|c|c|}
\hline & $\begin{array}{ll}\text { 1. } & \text { Sirih } \\
\text { 2. } & \text { Merica } \\
\text { 3. } & \text { Masuwi } \\
\text { 4. } & \text { Jebug/pinan } \\
& \mathrm{g} \\
\end{array}$ & $\begin{array}{ll}\text { 1. } & \text { Daun yang tua } \\
\text { 2. } & \text { Buah } \\
\text { 3. } & \text { Kulit batang } \\
\text { 4. } & \text { Buah }\end{array}$ & $\begin{array}{l}\text { Dicampurkan, } \\
\text { dioleskan. }\end{array}$ & - \\
\hline & $\begin{array}{ll}\text { 1. } & \text { Sirih } \\
\text { 2. } & \text { Merica } \\
\text { 3. } & \text { Jasun } \\
\text { 4. } & \text { Jaringau }\end{array}$ & $\begin{array}{ll}\text { 1. } & \text { Daun tua } \\
\text { 2. } & \text { Buah } \\
\text { 3. } & - \\
\text { 4. } & \text { Batang/daun }\end{array}$ & $\begin{array}{l}\text { Disemburkan } \\
\text { pada tempat yang } \\
\text { terasa sakit, } \\
\text { setelah } \\
\text { disemburkan, } \\
\text { potong kecil-kecil } \\
\text { sampai menjadi } \\
\text { bubuk }\end{array}$ & - \\
\hline $\begin{array}{lr}\text { Obat } & \text { jika } \\
\text { menelan } & \text { terasa } \\
\text { sakit } & \end{array}$ & $\begin{array}{l}\text { 1. Mentimun } \\
\text { 2. Umbi kayu } \\
\text { tàwà }\end{array}$ & $\begin{array}{ll}\text { 1. } & \text { Buah } \\
\text { 2. } & \text { Umbi }\end{array}$ & $\begin{array}{l}\text { Semua diparut, } \\
\text { dibubuhi santan } \\
\text { kane, dioleskan } \\
\text { pada } \\
\text { kerongkongan. }\end{array}$ & - \\
\hline $\begin{array}{l}\text { Obat cacar jika } \\
\text { dia tidak enak } \\
\text { makan }\end{array}$ & $\begin{array}{ll}\text { 1. } & \text { Mentimun } \\
\text { 2. } & \text { Lengkuas } \\
\text { 3. } & \text { Gamongan } \\
\text { 4. } & \text { Kencur }\end{array}$ & $\begin{array}{ll}\text { 1. } & \text { Buah } \\
\text { 2. } & \text { Rimpang } \\
\text { 3. } & \text { Umbi } \\
\text { 4. } & \text { Rimpang }\end{array}$ & \begin{tabular}{l}
\multicolumn{3}{l}{ Disemburkan } \\
pada dada ke \\
bawah sampai \\
dengan lutut.
\end{tabular} & - \\
\hline $\begin{array}{lr}\text { Bedak pada } \\
\text { orang yang } \\
\text { kena cacar }\end{array}$ & $\begin{array}{ll}\text { 1. } & \text { Buah calagi } \\
\text { 2. } & \text { Lengkuas } \\
\text { 3. } & \text { Masui } \\
\text { 4. } & \text { Beras merah }\end{array}$ & $\begin{array}{ll}\text { 1. } & \text { Kulit buah } \\
\text { 2. } & \text { Rimpang } \\
\text { 3. } & \text { Kulit batang } \\
\text { 4. } & \text { Buah }\end{array}$ & $\begin{array}{l}\text { Dipanggang, } \\
\text { dioleskan. }\end{array}$ & - \\
\hline $\begin{array}{l}\text { Obat tidak bisa } \\
\text { makan }\end{array}$ & $\begin{array}{ll}\text { 1. } & \text { Cendana } \\
\text { 2. } & \text { Jebugarum }\end{array}$ & $\begin{array}{l}\text { 1. Kayu } \\
\text { 2. Daging buah }\end{array}$ & $\begin{array}{l}\text { Dioleskan pada } \\
\text { bahu. }\end{array}$ & - \\
\hline Pangrangkus & $\begin{array}{ll}\text { 1. } & \text { Lengkuas } \\
\text { 2. } & \text { Sirih } \\
\text { 3. } & \text { Bawang } \\
& \text { putih } \\
\text { 4. } & \text { Jaringau } \\
\text { 5. } & \text { Ketumbar }\end{array}$ & $\begin{array}{ll}\text { 1. } & \text { Rimpang } \\
\text { 2. } & \text { Daun tua } \\
\text { 3. } & \text { Umbi } \\
\text { 4. } & - \\
\text { 5. } & \text { Buah }\end{array}$ & Dioleskan & - \\
\hline & $\begin{array}{ll}\text { 1. } & \text { Sirih } \\
\text { 2. } & \text { Temu ros } \\
\text { 3. } & \text { Bawang } \\
& \text { putih } \\
\text { 4. } & \text { Jaringau } \\
\text { 5. } & \text { Maswi } \\
\text { 6. } & \text { Lombok } \\
& \text { rambat }\end{array}$ & $\begin{array}{ll}\text { 1. } & \text { Daun tua } \\
\text { 2. } & \text { Rimpang } \\
\text { 3. } & \text { Umbi } \\
\text { 4. } & - \\
\text { 5. } & - \\
\text { 6. } & \text { Buah }\end{array}$ & $\begin{array}{l}\text { Digoreng tanpa } \\
\text { minyak, dioleskan }\end{array}$ & - \\
\hline $\begin{array}{l}\text { Jika mearah } \\
\text { warna } \underline{p u h}\end{array}$ & $\begin{array}{ll}\text { 1. } & \text { Temu tis } \\
\text { 2. } & \text { Bawang } \\
\text { 3. } & \text { Ketumbar }\end{array}$ & $\begin{array}{ll}\text { 1. } & \text { Rimpang } \\
\text { 2. } & \text { Umbi } \\
\text { 3. } & \text { Buah }\end{array}$ & Disemburkan. & - \\
\hline Paperes aksi & $\begin{array}{l}\text { 1. } \begin{array}{l}\text { Bawang } \\
\text { putih }\end{array} \\
\text { pun }\end{array}$ & 1. Umbi & $\begin{array}{ll}\text { Diperas } & \text { pada } \\
\text { orang } & \text { yang }\end{array}$ & - \\
\hline
\end{tabular}




\begin{tabular}{|c|c|c|c|c|}
\hline & & & $\begin{array}{l}\text { dakangnya belum } \\
\text { keluar. }\end{array}$ & \\
\hline $\begin{array}{l}\text { Obat, sakit } \\
\text { perut melilit }\end{array}$ & $\begin{array}{ll}\text { 1. } & \text { Sirih } \\
\text { 2. } & \text { Asam }\end{array}$ & $\begin{array}{l}\text { 1. Daun yang tua } \\
\text { 2. Daging buah }\end{array}$ & $\begin{array}{lr}\text { Daun sirih } & \text { tua } \\
\text { digoreng } & \text { tanpa } \\
\text { minyak, } & \text { asam, } \\
\text { garam } & \text { uku, } \\
\text { tempelkan } & \text { pada } \\
\text { pusar. } & \end{array}$ & - \\
\hline $\begin{array}{l}\text { Menghidupkan } \\
\text { dakang }\end{array}$ & $\begin{array}{ll}\text { 1. } & \text { Sirih } \\
\text { 2. } & \text { Temu ros } \\
\text { 3. } & \text { Merica } \\
\text { 4. } & \text { Cabe } \\
& \text { bungkut }\end{array}$ & $\begin{array}{ll}\text { 1. } & \text { Daun yang tua } \\
\text { 2. } & \text { Rimpang } \\
\text { 3. } & \text { Buah } \\
\text { 4. } & \text { Buah }\end{array}$ & $\begin{array}{l}\text { Dilumatkan, } \\
\text { kemudian } \\
\text { dioleskan. }\end{array}$ & - \\
\hline $\begin{array}{l}\text { Obat dakang } \\
\text { api }\end{array}$ & $\begin{array}{ll}\text { 1. } & \text { Sirih } \\
\text { 2. } & \text { Temu ros } \\
\text { 3. } & \text { Cabe } \\
\text { 4. } & \text { Kacang } \\
& \text { hijau }\end{array}$ & $\begin{array}{ll}\text { 1. } & \text { Daun yang tua } \\
\text { 2. } & \text { Rimpang } \\
\text { 3. } & \text { Buah } \\
\text { 4. } & \text { Biji }\end{array}$ & $\begin{array}{l}\text { Dilumatkan } \\
\text { kemudian } \\
\text { dioleskan. }\end{array}$ & - \\
\hline $\begin{array}{ll}\text { Obat dakang } \\
\text { dedek }\end{array}$ & $\begin{array}{ll}\text { 1. Jebug/pinan } \\
\mathrm{g} \\
\text { 2. } \\
\text { Bawang } \\
\text { putih } \\
\text { 3. Jaringau }\end{array}$ & $\begin{array}{ll}\text { 1. } & \text { Buah } \\
\text { 2. Umbi } \\
\text { 3. } & \text { Rimpang }\end{array}$ & $\begin{array}{l}\text { Dibakar, } \\
\text { dilumatkan } \\
\text { kemudian } \\
\text { dioleskan. }\end{array}$ & - \\
\hline $\begin{array}{l}\text { Obat dakang } \\
\text { yang } \\
\text { membengkak }\end{array}$ & $\begin{array}{l}\text { 1. Antawali } \\
\text { 2. } \\
\text { Lengkuas }\end{array}$ & $\begin{array}{ll}\text { 1. } & - \\
\text { 2. } & \text { Rimpang }\end{array}$ & $\begin{array}{l}\text { Dihangatkan } \\
\text { (tambus), } \\
\text { digosokan, } \\
\text { kemudian oleskan } \\
\text { pada yang } \\
\text { membengkak. }\end{array}$ & - \\
\hline $\begin{array}{lr}\text { Obat } & \text { dakang } \\
\text { adasar } & \text { bintul, } \\
\text { dan } & \text { bengah } \\
\text { (perih) } & \end{array}$ & $\begin{array}{ll}\text { 1. } & \text { Sirih } \\
\text { 2. } & \text { Temu ros } \\
\text { 3. } & \text { Merica } \\
\text { 4. } & \text { Lombok }\end{array}$ & $\begin{array}{ll}\text { 1. } & \text { Daun tua } \\
\text { 2. } & \text { Rimpang } \\
\text { 3. } & \text { Buah } \\
\text { 4. } & \text { Buah }\end{array}$ & $\begin{array}{l}\text { Dibakar, } \\
\text { dilumatkan, } \\
\text { dioleskan pada } \\
\text { yang terlihat } \\
\text { memerah. }\end{array}$ & - \\
\hline $\begin{array}{l}\text { Obat dakang } \\
\text { paburinik, } \\
\text { tidak } \\
\text { memuncak } \\
\text { (bintulnya tidak } \\
\text { muncul) }\end{array}$ & $\begin{array}{l}\text { 1. Bawang } \\
\text { 2. Beras merah }\end{array}$ & $\begin{array}{l}\text { 1. Umbi } \\
\text { 2. Buah }\end{array}$ & Dioleskan & - \\
\hline Obat ngéncéd & $\begin{array}{ll}\text { 1. } & \text { Sirih } \\
\text { 2. } & \text { Ketumbar }\end{array}$ & $\begin{array}{l}\text { 1. Daun yang tua } \\
\text { 2. Buah }\end{array}$ & $\begin{array}{l}\text { Dioleskan pada } \\
\text { semua jari kaki. }\end{array}$ & - \\
\hline
\end{tabular}




\section{SIMPULAN}

Dari penelitian pada Lontar Usada Kacacar yang dilakukan, dapat disimpulkan sebagai berikut:

1. Pada lontar Kacacar terdapat 75 jenis obat untuk gejala cacar dengan 100 jenis formula pengobatan yang menggunakan tumbuhan.

2. Tumbuhan pada lontar Kacacar terdapat 107 tumbuhan yang digunakan baik dengan tunggal atau campuran.

3. Penggunaan obat pada lontar Kacacar dengan cara disemburkan, dioleskan, ditempelkan, dimandikan, dibedakan, diminum, dimakan, dibubuhkan, ditambal dan diteteskan. Sediaan obat yang digunakan dalam pengobatan yaitu simbuhan, bedak, loloh/jamu dan boreh.

\section{DAFTAR PUSTAKA}

Anonim, 2014, Konservasi Naskah Lontar, Denpasar: Kantor Dokumentasi Budaya Bali.

Barlina, R., 2004, Potensi Buah Kelapa Muda Untuk Kesehatan dan Pengolahannya
Volume 3 Nomor 2, Manado Chawdri, L.R, 2003, Rahasia Yantra, Mantra \& Tantra, Surabaya : Paramita.

Kanginan, Jro, 1997, Alih Aksara lontar Usada Kacacar, Bali: Karangasem.

Kurnianingtyas, W., 2008, Kualitas Hasil Penerjemahan Individu Dan Penerjemahan Kelompok (Studi Kasus Proses dan Hasil Penerjemahan Mahasiswa Pascasarjana Program Studi Linguistik Minat Utama Penerjemahan Universitas Sebelas Maret Surakarta), Surakarta: Universitas Sebelas Maret.

Latief, A., 2012, Obat Tradisional, Jakarta: Buku Kedokteran EGC.

Nala, N., 2006, Aksara Bali dalam Usada, Denpasar: Paramita.

Pulasari, J.M., dan Artana, J.M.N, 2011, Usadha Bali Agung, Surabaya: Paramita.

Sukartha, I.N, 2014, Ilmu Pengobatan Ayur Veda Bali, Jumantara. 